\title{
WATER RELATIONS OF BLACK SPRUCE TREES ON A PEATLAND DURING WET AND DRY YEARS
}

\author{
Steeve Pepin ${ }^{1,4}$, André P. Plamondon ${ }^{2}$, and Abderraouf Britel ${ }^{3}$ \\ ${ }^{1}$ Institute of Botany \\ University of Basel \\ Schönbeinstrasse 6 \\ CH-4056 Basel \\ Switzerland \\ ${ }^{2}$ Centre de recherche en biologie forestière \\ Département des sciences du bois et de la forêt \\ Faculté de foresterie et de géomatique \\ Université Laval, Sainte-Foy, Québec, Canada, G1K 7P4 \\ ${ }^{3}$ Service des Eaux et Forêts \\ B.P. 405 \\ Tanger, Maroc \\ ${ }^{4}$ Present address: Ministère des Ressources naturelles \\ Forêt-Québec \\ Direction de la recherche forestière \\ 2700 rue Einstein, Sainte-Foy, Québec, Canada, G1P 3W8 \\ E-mail: steeve.pepin@mrn.gouv.qc.ca
}

\begin{abstract}
Low water tables typically found in peatlands during dry summer periods or in the vicinity of drainage ditches may lead to moisture deficiency in porous surface peats. Episodes of drought stress might compromise the growth benefits brought about by lower ground-water levels. We examined the water relations of black spruce (Picea mariana) trees on a natural peatland during relatively wet (1990) and relatively dry (1991) summers. Seasonal patterns of pre-dawn and mid-day shoot water potentials and stomatal conductance were not related to peat water content or to water-table depth. There was no evidence of water stress or osmotic adjustment in sampled trees during wet and dry growing seasons. Our soil moisture data showed that although water-table levels were as low as $-66 \mathrm{~cm}$ in 1991, water availability in the root zone remained high. Even with the absence of mid-day water stress during the summer of 1991, a $50 \%$ reduction in stomatal conductance as compared with the previous year was found. We suggest that signals from the bulk of the roots located in dry peat top layer contributed to the regulation of stomatal conductance.
\end{abstract}

Key Words: Picea mariana, shoot water relation parameters, stomatal conductance, forested bog, osmotic adjustment

\section{INTRODUCTION}

The cool and anaerobic soil conditions typically found in peatland forests affect the physiology of trees, particularly their water relations, photosynthesis, and mineral nutrition (Kozlowski 1982). Lowering of the water-table level through drainage or by evapotranspiration during summer dry periods improves the moisture, aeration, and thermal regimes of peat and increases nutrient availability (Hillman 1992, Prévost et al. 1999). Such improvements in edaphic conditions are generally associated with increased photosynthesis
(Macdonald and Lieffers 1990) and enhanced aboveand below-ground growth (Payandeh 1973, Lieffers and Rothwell 1987, Dang and Lieffers 1989, Paavilainen and Päivänen 1995, Macdonald and Yin 1999).

Some concerns have been presented that low water tables could occasionally lead to moisture deficiency during hot and dry summer periods (Braekke 1983, Berry and Jeglum 1988, Rothwell et al. 1996). This is because trees growing on organic soils have root systems that are predominantly confined to the unsaturated surface layers of peat (upper $20 \mathrm{~cm}$ ) (Lieffers and Rothwell 1987). Consequently, the effect of lowering 
the water table upon substrate water potential (Mannerkoski 1985) and the possible rapid decrease of peat moisture in the more fibrous surface layers (where most of the roots are located) could expose these trees to periods of water deficit during dry summers. High evaporative demand could also induce short-term water stress. Such episodes of water stress would thus limit tree growth and compromise the benefits brought about by low ground-water levels.

Although drought stress generally is associated with limited bulk soil-water resources, there is evidence that trees in natural peatlands can undergo periods of water stress during the afternoon (Dang et al. 1991). Insufficient tree water uptake in wet organic soils is usually attributed to the relatively small absorptive surface of shallow root systems and possibly reduced root hydraulic conductance because of low soil temperatures (Lopushinsky and Kaufmann 1984, Dang et al. 1991). However, it has also been suggested that tree species adapted to high soil water availability lack the mechanisms of drought tolerance that are commonly found in xeric and mesic species (Fan et al. 1994, Kubiske and Abrams 1994, Tognetti et al. 1997). It is thus possible that physiological processes in peatland trees are affected by even small reductions in root-zone water content. While the effects of flooding on tree physiology have been well-described (Kozlowski 1982, Macdonald and Lieffers 1990, Dang et al. 1991), there is little information on how peatland trees respond to occasional drying of the peat top layer.

In this study, we examined the water relations and stomatal conductance to water vapour $\left(\mathrm{g}_{\mathrm{s}}\right)$ of black spruce (Picea mariana (Mill.) BSP) trees on a natural peatland during two consecutive growing seasons. Our main objectives were to determine (1) whether peatland trees undergo periods of water stress when exposed to the drying of peat top layer produced by low water tables and (2) the physiological processes involved in their responses to seasonal drought. Relatively dry soil conditions were provided by a moderate summer drought in the second growing season.

\section{MATERIALS AND METHODS}

\section{Experimental Site}

We conducted this study in the richer part of a forested ombrotrophic bog of the Lotbinière district, about $50 \mathrm{~km}$ south-west of Québec City, Québec, Canada $\left(46^{\circ} 27^{\prime} \mathrm{N}, 71^{\circ} 23^{\prime} \mathrm{W}\right)$. The organic material, averaging $1 \mathrm{~m}$ in depth for the bog $(\sim 60 \mathrm{~cm}$ in our study site; area $\sim 1 \mathrm{ha}$ ), has accumulated on an impermeable compacted sandy till. The forest is a 45- to 55-yearold open black spruce stand, with tree heights up to $12 \mathrm{~m}$, a tree density of 950 trees ha ${ }^{-1}$, and a total basal area of $11 \mathrm{~m}^{2} \mathrm{ha}^{-1}$. Tamarack (Larix laricina (Du Roi) K. Koch) and balsam fir (Abies balsamea (L.) Mill.) are present as companion species. Sphagnum spp. covers the ground, Pleurozium schreberi (Brid.) Mitt., and Polythricum strictum Banks. are dominant species on the hummocks, and Nemopanthus mucronatus (L.) Trel. is the chief shrub.

The climate is cold and humid, with a growing season (daily mean temperature above $+5^{\circ} \mathrm{C}$ ) lasting on average 185 days and reaching 1660 degree-days (Dumas-Rousseau 1975). Mean July and January temperatures are 18.5 and $-12.5^{\circ} \mathrm{C}$, respectively. Total annual precipitation for the region averages $957 \mathrm{~mm}$, of which two-thirds falls during the growing season. The potential evapotranspiration for the area estimated by Thornthwaite's method is $560 \mathrm{~mm}$ (Wilson 1971).

Four undisturbed $260 \mathrm{~cm}^{3}$ peat samples were collected at 5, 10, 20,30,40, and $50 \mathrm{~cm}$ depth (while the water table was at $-6 \mathrm{~cm}$ ) to determine soil properties. Details of the sampling procedure are given in Pepin et al. (1992). These samples were kept saturated in the laboratory for $24 \mathrm{~h}$, and the following physical characteristics were measured: weight and volume at saturation, dry weight, bulk density, particle density, and total porosity. Based on those characteristics and the Canadian System of Soil Classification (Agriculture Canada Expert Committee on Soil Survey 1987), the material was found to be fibric at $5 \mathrm{~cm}$, mesic in the $10-40 \mathrm{~cm}$ layer, and humic at $50 \mathrm{~cm}$ and was classified as a Typic Mesisol. Roots were predominantly located within the upper $10-15 \mathrm{~cm}$ peat layer, with maximum rooting depth occasionally reaching $20 \mathrm{~cm}$ (measured in four different soil pits).

\section{Shoot Water Relations}

Tree water status was monitored during both growing seasons by measuring pre-dawn $\left(\Psi_{\text {pre }}\right)$ and mid-day $\left(\Psi_{\text {mid }}\right)$ shoot water potential (Ritchie and Hinckley 1975). Four twigs per tree were excised with a pruning pole at 0200 and $1400 \mathrm{~h}$ from lateral branches in the upper third of the crown of five dominant-codominant black spruce distributed on the site (area $\sim 0.1$ ha). Excised twigs were immediately sealed in humidified plastic bags, placed in a cooler, and brought back to the lab for determinations of $\Psi$ with a pressure chamber (model 610, PMS Instruments, Corvallis, OR, USA). The variability among all 20 readings was rarely greater than $0.1 \mathrm{MPa}$.

Water relations parameters of four healthy dominant-codominant trees (also used for measurements of stomatal conductance) were determined through the analysis of pressure-volume (PV) curves (Cheung et al. 1975, 1976, Kandiko et al. 1980, Ritchie and Shula 1984) on three sampling dates in each growing season. 
Twigs were collected between 0200 and $0300 \mathrm{~h}$, stored in plastic bags, and then recut under water in the laboratory and left to saturate overnight. On the next morning, PV curves were obtained using the procedure of Hinckley et al. (1980). Afterwards, sample shoots were oven-dried at $65^{\circ} \mathrm{C}$ for $48 \mathrm{~h}$ and their dry weight determined.

Osmotic potentials were estimated according to the "PVC" exponential model of Schulte and Hinckley (1985). The osmotic potential at full saturation $\left(\Psi_{\pi, \text { sat }}\right)$ and turgor loss point $\left(\Psi_{\pi, \mathrm{tlp}}\right)$ and the relative water content at turgor loss point $\left(\mathrm{R}_{\mathrm{tlp}}\right)$ were calculated with a non-linear least squares routine using the Marquardt algorithm (SAS Institute 1985). Bulk tissue elastic modulus (E) was calculated after Roberts et al. (1981) and $\mathrm{E}_{\max }$ data, which correspond to bulk modulus of elasticity at full turgor, were taken at $\mathrm{R}$ values of 100 and 97\% (Colombo 1987, Grossnickle 1989).

\section{Stomatal Conductance}

Diurnal patterns of stomatal conductance $\left(g_{s}\right)$ were measured during 10 days (5 July-27 Aug) in 1990 and 8 days (4 July-29 Aug) in 1991 under clear or partly cloudy conditions. Scaffolds were installed to provide access to branches in the upper third of the crown of four spruces. Four one-year-old shoots (one per branch) were labeled on each tree and measured repeatedly. Measurements of $g_{s}$ were made every $2 \mathrm{~h}$ between 0700 and $1900 \mathrm{~h}$ using a steady-state diffusion porometer (LI-1600, Li-Cor Inc., Lincoln, NE, USA) with a conifer cuvette. The sampling periods started when the foliage was dry in the morning. New one-year-old shoots were selected on the same branches in the second growing season. Additional $\mathrm{g}_{\mathrm{s}}$ measurements were carried out on two codominant balsam fir trees (located $\sim 50 \mathrm{~m}$ away from the sampled spruce trees) following the same procedure. Values of $g_{s}$ were corrected for the total foliage area enclosed in the chamber (Eq. A1, LI-COR 1989). The foliage area of each shoot used for $g_{s}$ measurements was determined at the end of the growing season using a digital imaging analysis system (model DIAS, Decagon Devices Inc., Pullman, WA, USA). Total foliage area (all sides) was then calculated using a ratio of total to projected needle surface area of 2.3 (determined following the procedures of Brand (1987), $\mathrm{n}=25$ samples of 5 spruce needles). A ratio of 2 was assumed to calculate the total surface area of balsam fir needles. Foliage area enclosed in the cuvette was corrected for the few needles that were lost during the measurement period.

Air temperature and relative humidity were measured every half hour with a psychrometer (model 566, Bendix, Baltimore, MD, USA) and used to calculate the atmospheric vapour pressure deficit (VPD). All po- rometer measurements were made at ambient humidities between 20 and $70 \%$.

\section{Soil Moisture Conditions}

The water regime of the peat was measured during both growing seasons. Water-table levels were measured in nine ground-water wells (perforated plastic pipes: $4 \mathrm{~cm}$ in diameter and $1 \mathrm{~m}$ long) distributed on the site. The moisture content of peat was determined using time-domain reflectometry (TDR). Details of measurement techniques and calibration in peat substrate can be found in Pepin et al. (1992). TDR measurements were carried out with a cable tester (model 1502, Tektronix, Beaverton, OR, USA) in one pit during the first growing season, and one more pit was installed before the second growing season. TDR probes were inserted horizontally at $5,10,20$, and 30 $\mathrm{cm}$ depths into a wall of each pit carefully dug and refilled. These TDR profiles were located at $\sim 3$ and $10 \mathrm{~m}$ from the trees sampled for $\mathrm{g}_{\mathrm{s}}$. Measurements of the water-table depths and TDR readings were performed every 2-3 days between May and October. Daily precipitation was monitored at the site with a Belfort rain gauge and recorded hourly with a datalogger (CR10, Campbell Scientific, Logan, UT, USA).

\section{Data Analyses}

Kolomogorov D statistic and Bartlett's test were used to verify assumptions of normality and homogeneity of variances, respectively. Pre-dawn and midday water potentials and daily maximum stomatal conductance were compared between years using analysis of variance. Changes in shoot water relations parameters during a growing season were compared using the Waller-Duncan method. All statistical analyses were performed on the SAS system (SAS Institute 1985) with a level of significance of $P \leq 0.05$.

\section{RESULTS}

\section{Soil Moisture Conditions}

May to September 1990 and 1991 rainfalls were 612 and $403 \mathrm{~mm}$, respectively (Figure 1). The average and lowest water-table depths measured at the site were, respectively, -13.3 and $-23.9 \mathrm{~cm}$ during the first growing season and -29.6 and $-66.4 \mathrm{~cm}$ during the second. There was no significant seasonal change in peat moisture content in 1990. Overall, peat water content remained very close to saturation at all depths during the first growing season. The moisture contents were, under saturated soil conditions, higher in the surface horizons than at $20-$ and $30-\mathrm{cm}$ depth. This was 

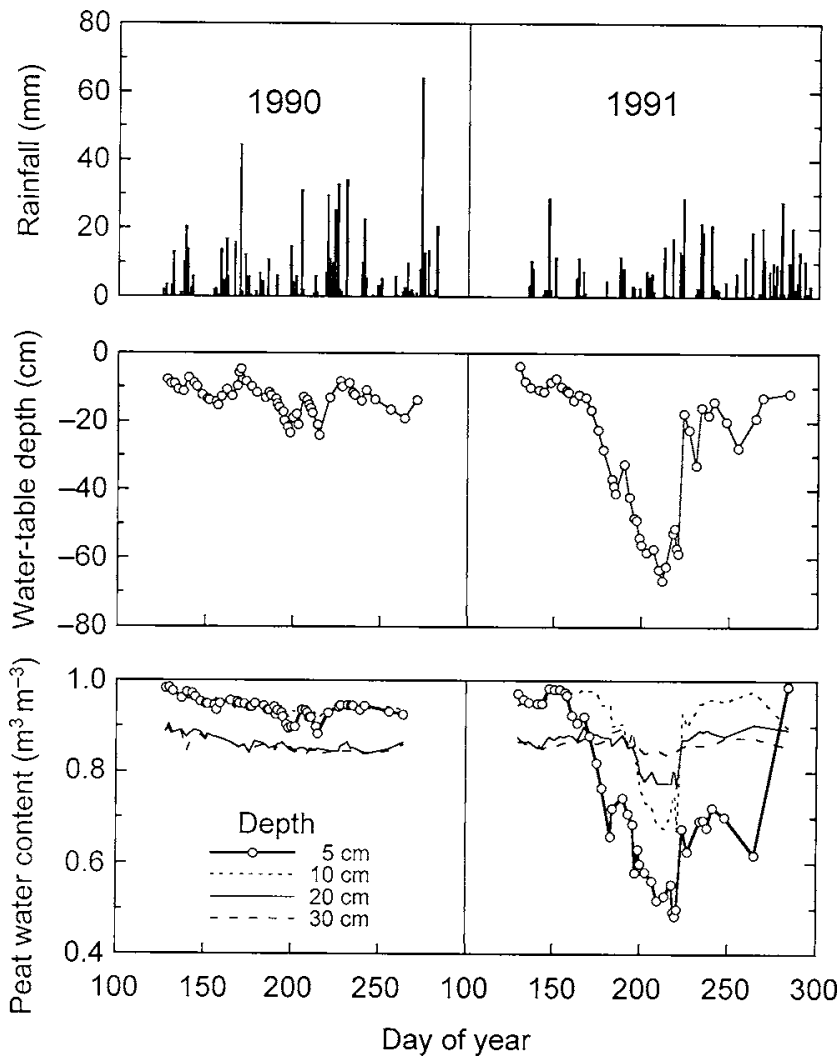

Figure 1. Rainfall, water-table depth, and volumetric peat water content at $5,10,20$, and $30 \mathrm{~cm}$ depths during wet (1990) and dry (1991) growing seasons. In the middle panel, $0 \mathrm{~cm}$ indicates the peat surface.

attributable to a greater peat porosity in the surface layers $(5,10 \mathrm{~cm})$.

Soil drying was observed only at the 5-cm depth for few days in 1990 (changes $<0.10 \mathrm{~m}^{3} \mathrm{~m}^{-3}$ ). In contrast, a pronounced decrease in peat water content was observed at 5 and $10 \mathrm{~cm}$ during the second season (Figure 1). When the water table was at its lowest level, moisture contents were 0.48 and $0.67 \mathrm{~m}^{3} \mathrm{~m}^{-3}$ at the 5and $10-\mathrm{cm}$ depth, respectively. There was only a slight seasonal decrease in water content at the $20-\mathrm{cm}$ depth $\left(\sim 0.12 \mathrm{~m}^{3} \mathrm{~m}^{-3}\right)$ and almost no change $\left(<0.05 \mathrm{~m}^{3} \mathrm{~m}^{-3}\right)$ at $30 \mathrm{~cm}$.

\section{Water Relations}

During the wet 1990 growing season, there was a significant decrease in osmotic potential at saturation $\left(\Psi_{\pi, \text { sat }}\right)$ but little change in osmotic potential at turgor loss point $\left(\Psi_{\pi, \text { tlp }}\right)$ (Table 1$)$. Mid-day water potentials measured on 17 July, 3 and 23 August (mean $=-1.56$ $\mathrm{MPa}$ ) were all greater than corresponding $\Psi_{\pi, \mathrm{tlp}}$ (mean $=-2.25 \mathrm{MPa})$. The relative water content at turgor loss point $\left(\mathrm{R}_{\mathrm{tp}}\right)$ and maximum modulus of elasticity $\left(E_{\max }\right)$ both increased between the first two sampling

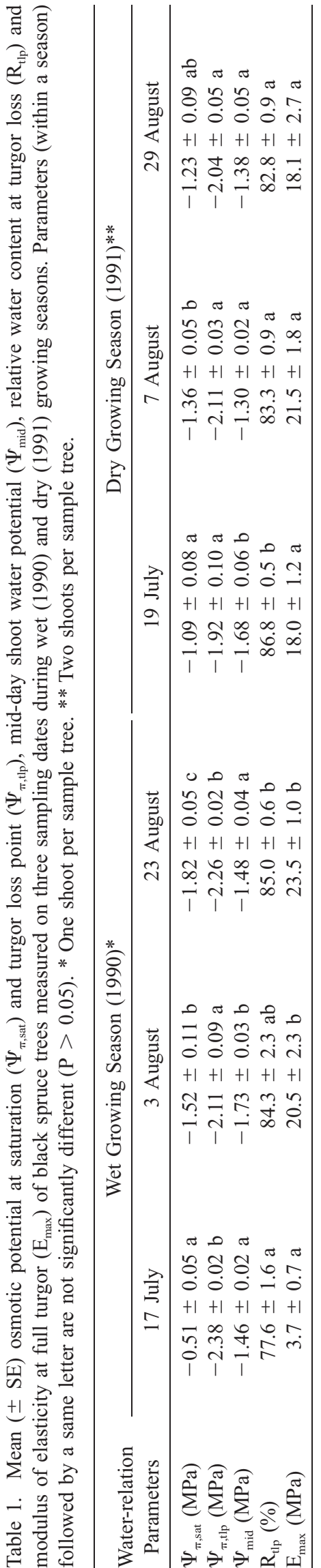




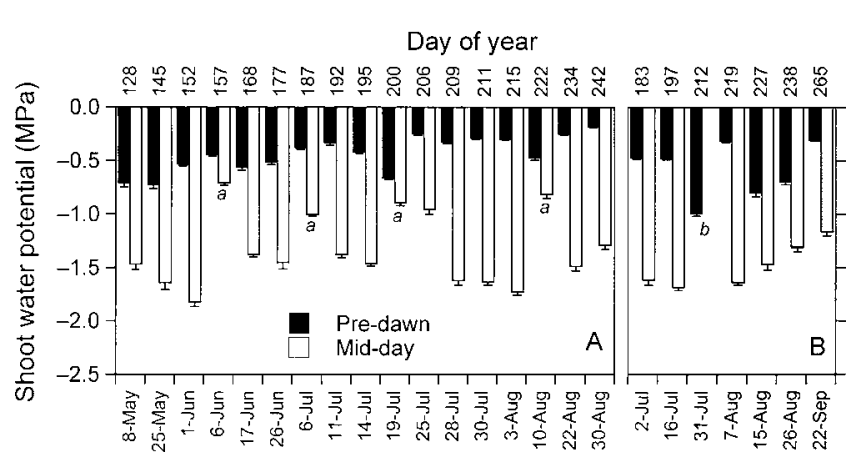

Figure 2. Seasonal changes in daily pre-dawn (solid bars) and mid-day (shaded bars) shoot water potentials (mean \pm $\mathrm{SE}, \mathrm{n}=20$ ) of black spruce trees during (A) wet (1990) and (B) dry (1991) growing seasons. Sampling dates and corresponding 'day of year' are indicated. $a$ : cloudy day; $b$ : no mid-day measurements because of rain.

dates in 1990 and remained at that level for the last measurement. The low $\mathrm{E}_{\max }$ measured on 17 July 1990 suggested that shoot elongation was still in process (not measured). This is consistent with the observed late bud burst (mid-June) in the wet compared to dry year (late May).

In general, there were only small seasonal changes in shoot water-relations attributes throughout the dry 1991 summer (Table 1). However, on the first sampling date, lower $\Psi_{\pi, \text { sat }}$ and greater $\Psi_{\pi, \mathrm{tp}}, \mathrm{R}_{\mathrm{tlp}}$ and $\mathrm{E}_{\mathrm{max}}$ were found in 1991 than in 1990. The mid-day water potentials measured on 19 July, 7 and 29 August (mean $=-1.45 \mathrm{MPa})$ were all higher than the osmotic potentials at turgor loss point measured on the same days (mean $=-2.02 \mathrm{MPa}$ ). Interestingly, the lowest (more negative) osmotic potentials (both $\Psi_{\pi, \text { sat }}$ and $\Psi_{\pi, \mathrm{tlp}}$ ) were observed during the wet growing season.

Despite significant differences in soil moisture regime between both growing seasons, pre-dawn $\left(\Psi_{\text {pre }}\right)$ and mid-day $\left(\Psi_{\text {mid }}\right)$ shoot water potentials were generally similar (Figure 2). Under the wet soil conditions of the 1990 season, mean pre-dawn water potentials ranged between -0.18 and $-0.72 \mathrm{MPa}$, and mean mid-day water potentials varied between -0.71 and $-1.83 \mathrm{MPa}$ (Figure 2). During the dry 1991 growing season, mean values of $\Psi_{\text {pre }}$ and $\Psi_{\text {mid }}$ ranged from -0.30 to $-0.99 \mathrm{MPa}$ and -1.16 to $-1.88 \mathrm{MPa}$, respectively. Mid-day $\Psi$ were occasionally measured on cloudy days in 1990 (see Figure 2) and thus, these data were excluded from the calculation of seasonal mean (Table 2). The seasonal average of daily $\Psi_{\text {pre }}$ was slightly lower in dry than wet year $(\mathrm{P}<0.001)$.

\section{Stomatal Conductance}

In general, diurnal patterns of stomatal conductance $\left(g_{s}\right)$ were similar between both growing seasons (Figure 3). Typically, stomatal conductance was high in the morning when the vapour pressure deficit (VPD) was low and decreased gradually with increasing VPD throughout the day. Some sampling dates showed very little diurnal change $(<10 \%)$ in $\mathrm{g}_{\mathrm{s}}$, while the average daily reductions were 28 and $39 \%$ during the wet and dry growing season, respectively.

The stomatal conductance of black spruce foliage was reduced by $54 \%$ in 1991 , with a seasonal average of $14.0 \mathrm{mmol} \mathrm{m}^{-2} \mathrm{~s}^{-1}$ as compared to $30.5 \mathrm{mmol} \mathrm{m}^{-2}$ $\mathrm{s}^{-1}$ in summer 1990 (Figure 4a). A similar reduction in $\mathrm{g}_{\mathrm{s}}$ was observed in two individuals of a companion species (A. balsamea: seasonal average of 40.7 and $21.1 \mathrm{mmol} \mathrm{m}^{-2} \mathrm{~s}^{-1}$ in summer 1990 and 1991, respectively) (Figure 4b). However, the mean daily maximum $g_{s}$ was only $27 \%$ lower in the dry than wet growing season (Table 2). The drier soil conditions observed in 1991 were also associated with higher vapour pressure deficits. Maximum vapour pressure deficits were about 3.5-4.0 kPa during dry 1991 summer while VPD reached 2.5-3.0 $\mathrm{kPa}$ in summer 1990 (Figure 4). No significant difference in stomatal sensitivity to VPD could be detected between both growing seasons.

\section{DISCUSSION}

\section{Water Relations}

The water status of peatland trees was not adversely affected by drying of the peat top layer. When exposed to relatively low water tables and concomitant dry peat surfaces, black spruce trees had pre-dawn $\left(\Psi_{\text {pre }}\right)$ and mid-day $\left(\Psi_{\text {mid }}\right)$ shoot water potentials similar to those under high ground-water levels (Figure 2, Table 2). It is generally assumed that, following overnight recovery, pre-dawn $\Psi$ corresponds to the equilibrium be-

Table 2. Seasonal averages ( \pm SE, and $n$ in parentheses) of daily pre-dawn $\left(\Psi_{\text {pre }}\right)$ and mid-day $\left(\Psi_{\text {mid }}\right)$ shoot water potentials, and daily maximum stomatal conductances $\left(\mathrm{g}_{\mathrm{s}, \max }\right)$ of black spruce trees during wet (1990) and dry (1991) growing seasons. Values followed by the same letter are not significantly different $(\mathrm{P}>0.05)$ between seasons.

\begin{tabular}{lcc}
\hline \multicolumn{1}{c}{ Parameters } & Wet Growing Season & Dry Growing Season \\
\hline$\Psi_{\text {pre }}(\mathrm{MPa})$ & $-0.43 \pm 0.01 \mathrm{a}(328)$ & $-0.58 \pm 0.02 \mathrm{~b} \mathrm{(137)}$ \\
$\Psi_{\text {mid }}(\mathrm{MPa})$ & $-1.49 \pm 0.02 \mathrm{a} \mathrm{(245)}$ & $-1.48 \pm 0.02 \mathrm{a} \mathrm{(117)}$ \\
$\mathrm{g}_{\mathrm{s}, \text { ax }}\left(\mathrm{mmol} \mathrm{m} \mathrm{m}^{-2} \mathrm{~s}^{-1}\right)$ & $45.9 \pm 1.8 \mathrm{a} \mathrm{(10)}$ & $33.4 \pm 3.3 \mathrm{~b} \mathrm{(8)}$ \\
\hline
\end{tabular}



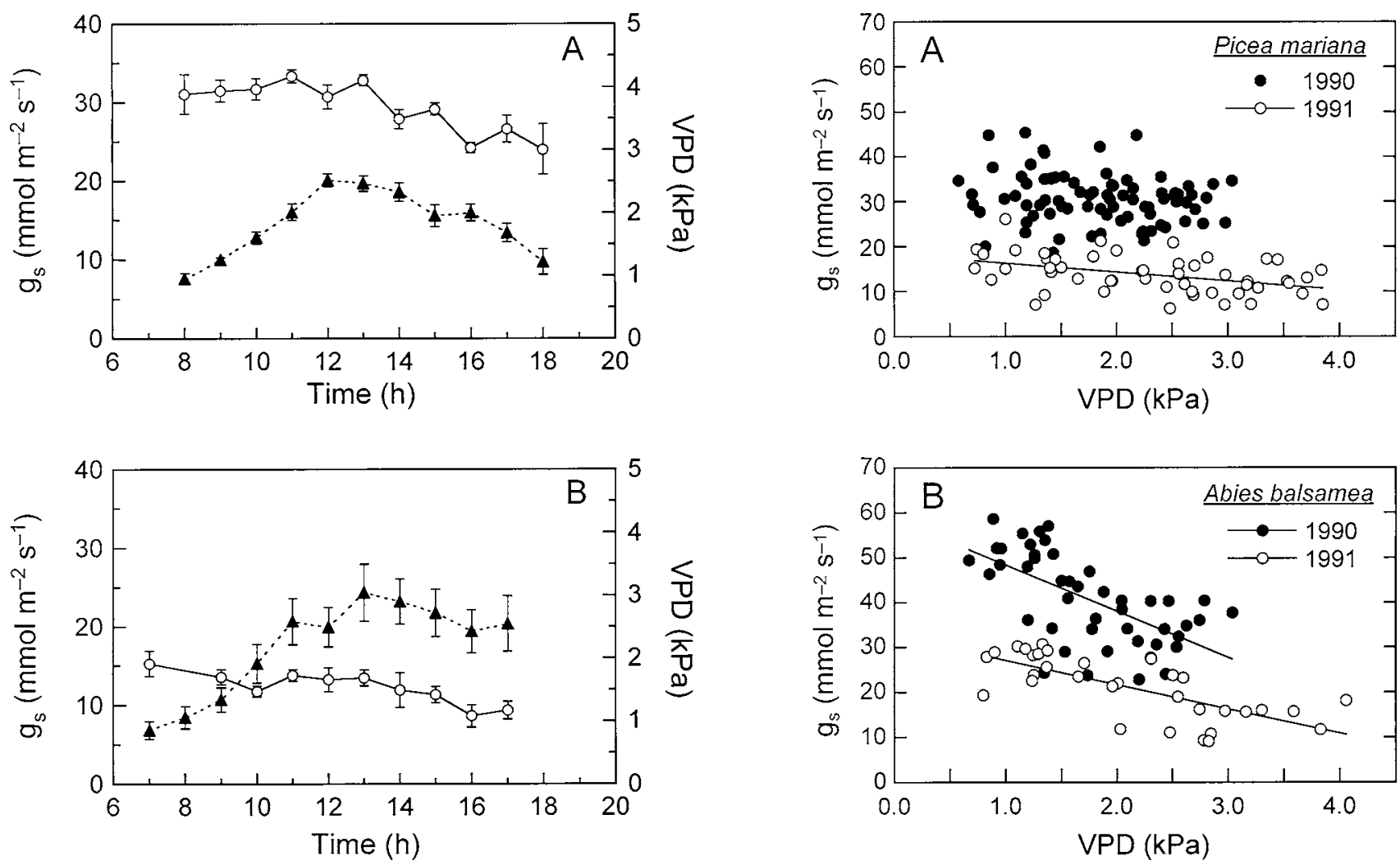

Figure 3. Diurnal course of stomatal conductance to water vapour $\left(g_{s}\right.$; circle) measured on four black spruce trees during (A) wet (1990; $\mathrm{n}=10$ days) and (B) dry (1991; $\mathrm{n}=8$ days) growing seasons. Measurements were carried out on four shoots per individual and averaged $(n=16)$ per hour. Each data point is the mean ( $\pm \mathrm{SE}$ ) of three to seven sampling days (measurement periods occasionally started on the odd hour when foliage was covered with dew). Also shown is the atmospheric vapour pressure deficit (VPD; triangle). Means without vertical bars indicate that SE is smaller than the symbol.

tween plant and soil water potential, and thus reflects soil water status (but see Sellin 1999). Although the lowest $\Psi_{\text {pre }}$ measured in this study occurred when the water table was at its deepest level (31 July 1991), there was overall no significant relationship between $\Psi_{\text {pre }}$ and peat moisture content at any depth $\left(\mathrm{R}^{2}<0.10\right.$, $\mathrm{P}>0.52)$. Values of $\Psi_{\text {pre }}$ and $\Psi_{\text {mid }}$ presented here are within the -0.4 to $-2.2 \mathrm{MPa}$ range reported for black spruces on natural peatlands under saturated soil conditions (Dang et al. 1991) and during a dry growing season (Dang et al. 1997).

Despite lower peat water content in the dry compared to wet year, the matric potentials and hence soil water availability remained relatively high. At the lowest water-table level of $-66 \mathrm{~cm}$, the water content at 5,10 , and $20 \mathrm{~cm}$ depths corresponded to matric potentials above $-0.02 \mathrm{MPa}$ according to Paavilainen and Päivänen (1995) and the relations established by

Figure 4. Hourly average stomatal conductance to water vapour $\left(\mathrm{g}_{\mathrm{s}}\right)$ in relation to the atmospheric vapour pressure deficit measured during wet (1990; closed symbols) and dry (1991; open symbols) growing seasons. (A) Data are averages of 16 shoots measured on four black spruce trees; dry season: $18.4-2.0 \cdot \mathrm{VPD}, \mathrm{R}^{2}=0.18$. (B) Data are averages of 8 shoots measured on two balsam fir trees; wet season: $58.7-$ 10.3 $\cdot \mathrm{VPD}, \mathrm{R}^{2}=0.39$; dry season: $32.5-5.4 \cdot \mathrm{VPD}, \mathrm{R}^{2}=0.53$.

Belleau (1988) on a nearby site. Although this may explain the lack of differences in shoot water potentials between wet and dry years (also observed in 2 balsam fir trees; data not shown), it does not account for the reductions in stomatal conductance observed during the summer of 1991 (Figures 3 and 4). Another possibility is that physiological adjustment occurred to maintain a constant $\Psi$. Our water-relations parameters indicate that trees maintained turgor throughout both wet and dry growing seasons, but there were no seasonal elastic or osmotic adjustments associated with the drier soil conditions of 1991 (Table 1). Many studies have shown that the responses of black spruce to water stress can involve the regulation of turgor through active osmotic adjustment (Zwiazek and Blake 1989, Tan et al. 1992) or changes in cell wall elasticity (Blake et al. 1991, Fan et al. 1994) and/or the acclimation of stomatal and photosynthetic mechanisms (Zine El Abidine et al. 1994).

$\mathrm{CO}_{2}$ assimilation (A) in black spruce is mostly limited by mesophyll processes during water stress (Stew- 
art et al. 1995) or under wet soil conditions (Dang et al. 1991, Kubiske and Abrams 1993). However, there is evidence that stomatal limitation to A increases later in the growing season (Dang et al. 1997). It has been proposed that the aperture of stomata is regulated to minimize the risk of xylem cavitation by maintaining shoot water potentials above threshold values and possibly maximize, in the short-term, carbon assimilation and productivity (Jones and Sutherland 1991, Sperry 1995, Williams et al. 1996). In mature black spruce trees, stomatal conductance has been found to decrease continuously in response to falling shoot water potential, whereas net photosynthesis and mesophyll conductance have threshold $\Psi$ values of about $-2.5 \mathrm{MPa}$ (Dang et al. 1997). The lowest mid-day water potentials reported in the literature for black spruce trees growing on organic soils ( -2.0 to $-2.2 \mathrm{MPa}$, including this study) approached but remained slightly above the threshold $\Psi$ for photosynthesis. This suggests that there are homeostatic adjustments (e.g., stomatal regulation, properties of the hydraulic pathway) that maintain shoot water potential within relatively narrow limits. The mechanisms underlying such responses are not known. However, Maier-Maercker (1998) recently described experiments that support the notion of negative feedback loop between $g_{s}$ and $\Psi$ and suggested that stomata respond directly to the ratio of water supply to water demand by the atmosphere.

\section{Stomatal Conductance}

The drier peat conditions of summer 1991 were associated with a $54 \%$ reduction in stomatal conductance $\left(g_{s}\right)$ and a $27 \%$ reduction in daily maximum $g_{s}$, as compared with the previous year (Figures 3 and 4, Table $2)$. This contrasts with the data of Macdonald and Lieffers (1990), who found that lowering the water table through drainage (average drop: $40-50 \mathrm{~cm}$ ) improved nitrogen relations but had no significant effect on stomatal conductance, up to 5 years after treatment. Further, the diurnal changes in $\mathrm{g}_{\mathrm{s}}$ observed in this study (mean daily reduction: $\sim 28$ and 39\% during wet and dry year, respectively) were much less pronounced than those reported by Dang et al. (1991) for black spruce trees on saturated peatland (mean daily reduction in $\mathrm{g}_{\mathrm{s}}: \sim 60 \%$ ). It is clear that $\mathrm{g}_{\mathrm{s}}$ is regulated by changes in the transpirational flux density within the tree, which accommodates the atmospheric demand for water with the supply of water from the soil (Monteith 1995). Dang et al. (1997) recently described the stomatal responses of black spruce trees to leaf-to-atmosphere vapour pressure difference (D) and demonstrated its importance in regulating gas exchange at the shoot level. The stomata of black spruce were only slightly sensitive to changes in VPD during the wet growing season, with an overall $11 \%$ decrease in $g_{\mathrm{s}}$ as VPD increased from 0.75 to $3.0 \mathrm{kPa}$ (Figure $4 \mathrm{a}$ ). Hence, it appears that under these conditions of high soil water availability, there was sufficient water uptake by the trees over this range of evaporative demands (also supported by the water potential measurements). A greater stomatal sensitivity to VPD was found during the dry summer of 1991, where $g_{s}$ decreased by nearly $40 \%$ with increasing VPD from 0.75 to $4.0 \mathrm{kPa}$. Such reductions in $\mathrm{g}_{\mathrm{s}}$ are more consistent with the observations of Dang et al. (1991; 50\% decrease in $\mathrm{g}_{\mathrm{s}}$ when VPD increased from 0.1 to $1.4 \mathrm{kPa}$ ) and of Dang et al. (1997; $60 \%$ decrease in $\mathrm{g}_{\mathrm{s}}$ for a change in $\mathrm{D}$ from 0.5 to $4.0 \mathrm{kPa}$ ). Assuming that $\mathrm{VPD} \approx \mathrm{D}$ for conifer foliage (i.e., the boundary layer conductance is large), the empirical model of Dang et al. (1997) clearly overestimates the values of $g_{s}$ found during the relatively dry soil conditions of summer 1991. Our results thus suggest that there might be additional mechanisms that could account for the reduction in stomatal conductance and the difference in the $\mathrm{g}_{\mathrm{s}}$ vs. VPD relationships between years.

There is evidence that in a drying soil, chemical root signals may reduce stomatal conductance without any detectable change in shoot water potential (Davies and Zhang 1991). Endogenous abscisic acid (ABA) produced in the roots and transported to the leaves via the xylem stream has been implicated in bringing about stomatal closure in drought-stressed herbaceous species (Schurr et al. 1992). In contrast, it is suggested that in woody species, ABA is sequestered in the leaf under well-watered soil conditions and subsequently released in the apoplast, as the soil dries, to act on the stomatal guard cells (Hartung and Slovik 1991). Small changes in leaf water status generally associated with soil drying or other perturbation to the hydraulic pathway in the xylem (but likely masked by measurement of bulk $\Psi$; Sperry et al. 1993) could trigger the redistribution of ABA in leaves (Fuchs and Livingston 1996, Whitehead et al. 1996). Although the stomata of woody plants do not appear fully responsive to signals generated in the roots (Saliendra et al. 1995, Fuchs and Livingston 1996), such responses have not been examined in tree species adapted to high soil water availability. Roots located in the more fibrous surface layers $(0-5 \mathrm{~cm})$ were occasionally exposed to peat moisture contents lower than $0.40 \mathrm{~m}^{3} \mathrm{~m}^{-3}$ during the dry summer of 1991. We suggest that despite high moisture availability in the root zone, small roots in the surface horizons of dry peat were dehydrated and that metabolites from these roots likely contributed to the stomatal regulation of transpiration (decrease in $\mathrm{g}_{\mathrm{s}}$ ), thus maintaining shoot turgor under conditions of high evaporative demand. Although consistent with our findings, such a hypothesis remains to be tested. Our results do 
not, however, rule out the possibility that $\mathrm{g}_{\mathrm{s}}$ is regulated by an interaction between chemical and hydraulic signals, as, for example, proposed by Tardieu and Davies (1993). The sensitivity of peatland trees to seasonal drought, and the physiological processes involved in their acclimative responses to soil drying, warrants further investigation, particularly in a context where future changes in temperature and precipitation regime may lead to increased soil water variability in organic soils.

\section{ACKNOWLEDGMENTS}

We thank Gilles Grégoire, Patrick Boutin, and Rachid Chebihi for assistance with the field measurements. We are grateful to Denis Lévesque for help in data retrieval and equipment maintenance and to Daïshowa Inc. for providing logistical support and the study site. We also thank Stéphane Dubé for his unpublished data of vegetation and soil surveys. Comments from Pierre Y. Bernier and two anonymous reviewers greatly improved this manuscript. This research was supported by the Natural Science and Engineering Research Council of Canada (NSERC), the Ministère des Ressources naturelles du Québec (MRN), and the Fonds pour la formation de chercheurs et l'aide à la recherche (FCAR).

\section{LITERATURE CITED}

Agriculture Canada Expert Committee on Soil Survey. 1987. Canadian System of Soil Classification. 2nd ed. Agriculture Canada Publication 1646.

Belleau, P. 1988. Drainage d'une pessière noire à sphaigne et à némopanthe mucroné. M.Sc. Thesis. Université Laval, Sainte-Foy, Québec, Canada.

Berry, G. J. and J. K. Jeglum. 1988. Water table profiles of drained, forested and clearcut peatlands in northern Ontario, Canada. Vol. 2, p. 72-79. In International Symposium on Hydrology of Wetlands in Temperate and Cold Climates. Joensuu, Finland.

Blake, T. J., E. Bevilacqua, and J. J. Zwiazek. 1991. Effects of repeated stress on turgor pressure and cell elasticity changes in black spruce seedlings. Canadian Journal of Forest Research 21: 1329-1333.

Braekke, F. H. 1983. Water levels at different drainage intensities on deep peat in northern Norway. Forest Ecology and Management 5:169-192.

Brand, D. G. 1987. Estimating the surface area of spruce and pine foliage from displaced volume and length. Canadian Journal of Forest Research 17:1305-1308.

Cheung, Y. N. S., M. T. Tyree, and J. Dainty. 1975. Water relations parameters on single leaves obtained in a pressure bomb and some ecological interpretations. Canadian Journal of Botany 53:13421346.

Cheung, Y. N. S., M. T. Tyree, and J. Dainty. 1976. Some possible sources of error in determining bulk elastic moduli and other parameters from pressure-volume curves of shoots and leaves. Canadian Journal of Botany 54:758-765.

Colombo, S. J. 1987. Changes in osmotic potential, cell elasticity, and turgor relationships of 2nd-year black spruce container seedlings. Canadian Journal of Forest Research 17:365-369.

Dang, Q. L. and V. J. Lieffers. 1989. Climate and tree ring growth of black spruce in some Alberta peatlands. Canadian Journal of Botany 67:1885-1889.

Dang, Q. L., V. J. Lieffers, R. L. Rothwell, and S. E. Macdonald. 1991. Diurnal variation and interrelations of ecophysiological parameters in three peatland woody species under different weather and soil moisture conditions. Oecologia 88:317-324.

Dang, Q. L., H. A. Margolis, M. R. Coyea, M. Sy, and G. J. Collatz. 1997. Regulation of branch-level gas exchange of boreal trees: roles of shoot water potential and vapor pressure difference. Tree Physiology 17:521-535.

Davies, W. J. and J. Zhang. 1991. Roots signals and the regulation of growth and development of plants in drying soil. Annual Review of Plant Physiology and Plant Molecular Biology 42:55-76.

Dumas-Rousseau, M. 1975. Les Régions Agricoles du Québec. Bibliothèque du Québec, Ministère de l'Agriculture du Québec, Quebec, PQ, Canada.

Fan, S., T. J. Blake, and E. Blumwald. 1994. The relative contribution of elastic and osmotic adjustments to turgor maintenance of woody species. Physiologia Plantarum 90:408-413.

Fuchs, E. E. and N. J. Livingston. 1996. Hydraulic control of stomatal conductance in Douglas fir [Pseudotsuga menziesii (Mirb.) Franco] and alder [Alnus rubra (Bong)] seedlings. Plant, Cell and Environment 19:1091-1098.

Grossnickle, S. C. 1989. Shoot phenology and water relations of Picea glauca. Canadian Journal of Forest Research 19:1287-1290.

Hartung, W. and S. Slovik. 1991. Physiochemical properties of plant growth regulators and plant tissues determine their distribution and redistribution: stomatal regulation by $\mathrm{ABA}$ in leaves. New Phytologist 119:361-382.

Hillman, G. R. 1992. Some hydrological effects of peatland drainage in Alberta's boreal forest. Canadian Journal of Forest Research 22:1588-1596.

Hinckley, T. M., F. Duhme, A. R. Hinckley, and H. Richter. 1980. Water relations of drought hardy shrubs: osmotic potential and stomatal reactivity. Plant, Cell and Environment 3:131-140.

Jones, H. G. and R. A. Sutherland. 1991. Stomatal control of xylem embolism. Plant, Cell and Environment 14:607-612.

Kandiko, R. A., R. Timmis, and J. Worral. 1980. Pressure-volume curves of shoots and roots of normal and drought conditioned western hemlock seedlings. Canadian Journal of Forest Research 10:10-16.

Kozlowski, T. T. 1982. Water supply and tree growth. Part II. Flooding. Forestry Abstract 43:145-161.

Kubiske, M. E. and M. D. Abrams. 1993. Stomatal and nonstomatal limitations of photosynthesis in 19 temperate tree species on contrasting sites during wet and dry years. Plant, Cell and Environment 16:1123-1129.

Kubiske, M. E. and M. D. Abrams. 1994. Ecophysiological analysis of woody species in contrasting temperate communities during wet and dry years. Oecologia 98:303-312.

LI-COR Inc. 1989. LI-1600 steady-state porometer Instruction Manual. Lincoln, NE, USA.

Lieffers, V. J. and R. L. Rothwell. 1987. Rooting of peatland black spruce and tamarack in relation to depth of the water table. Canadian Journal of Botany 65:817-821.

Lopushinsky, W. and M. R. Kaufmann. 1984. Effects of cold soil on water relations and spring growth of Douglas-fir seedlings. Forest Science 30:628-634.

Macdonald, S. E. and V. J. Lieffers. 1990. Photosynthesis, water relations, and foliar nitrogen of Picea mariana and Larix laricina from drained and undrained peatlands. Canadian Journal of Forest Research 20:995-1000.

Macdonald, S. E. and F. Y. Yin. 1999. Factors influencing size inequality in peatland black spruce and tamarack: evidence from post-drainage release growth. Journal of Ecology 87:404-412.

Maier-Maercker, U. 1998. Dynamics of changes in stomatal response and water status of Picea abies during a persistent drought period: a contribution to the traditional view of plant water relations. Tree Physiology 18:211-222.

Mannerkoski, H. 1985. Effect of Water Table Fluctuation on the Ecology of Peat Soil. Publications from the Department of Peatland Forestry, University of Helsinki, Helsinki, Finland.

Monteith, J. L. 1995. Accommodation between transpiring vegeta- 
tion and the convective boundary layer. Journal of Hydrology 166: 251-263.

Paavilainen, E. and J. Päivänen. 1995. Peatland Forestry. Ecology and Principles. Ecological Studies Series, Vol. 1110. SpringerVerlag, Berlin, Germany.

Payandeh, B. 1973. Analyses of a forest drainage experiment in Northern Ontario. 1. Growth analysis. Canadian Journal of Forest Research 3:387-398.

Pepin, S., A. P. Plamondon, and J. Stein. 1992. Peat water content measurement using time domain reflectometry. Canadian Journal of Forest Research 22:534-540.

Prévost, M., A. P. Plamondon, and P. Belleau. 1999. Effects of drainage of a forested peatland on water quality and quantity. Journal of Hydrology 214:130-143.

Ritchie, G. A. and T. M. Hinckley. 1975. The pressure chamber as an instrument for ecological research. Advances in Ecological Research 9:165-254.

Ritchie, G. A. and R. G. Shula. 1984 Seasonal changes of tissuewater relations in shoots and roots systems of Douglas-fir seedlings. Forest Science 30:538-548.

Roberts, S. W., B. R. Strain, and K. K. Knoerr. 1981. Seasonal variation of leaf tissue elasticity in four forest tree species. Physiologia Plantarum 52:245-250.

Rothwell, R. L., U. Silins, and G. R. Hillman. 1996. The effects of drainage on substrate water content at several forested Alberta peatlands. Canadian Journal of Forest Research 26:53-62.

Saliendra, N. Z., J. S. Sperry, and J. P. Comstock. 1995. Influence of leaf water status on stomatal response to humidity, hydraulic conductance, and soil drought in Betula occidentalis. Planta 196: $357-366$.

SAS Institute. 1985. SAS (Statistical Analysis System) User's guide-Statistics. Version 5. SAS Institute Inc., Cary, NC, USA.

Schulte, P. J. and T. M. Hinckley. 1985. A comparison of pressurevolume curve data analysis techniques. Journal of Experimental Botany 36:1590-1602.

Schurr, U., T. Gollan, and E. D. Schulze. 1992. Stomatal response to drying soil in relation to changes in the xylem sap composition of Helianthus annuus II. Stomatal sensitivity to ABA imported from the xylem sap. Plant, Cell and Environment 15:561-567.

Sellin, A. 1999. Does pre-dawn water potential reflect conditions of equilibrium in plant and soil water status? Acta Oecologia 20:5159.

Sperry, J. S., N. N. Alder, and S. E. Eastlack. 1993. The effect of reduced hydraulic conductance on stomatal conductance and $x y-$ lem cavitation. Journal of Experimental Botany 44:1075-1082.
Sperry, J. S. 1995. Limitations on stem water transport and their consequences. p. 105-124. In B. L. Gartner (ed.) Plant Stems: Physiology and Functional Morphology. Academic Press, San Diego, CA, USA.

Stewart, J. D., A. Zine El Abidine, and P. Y. Bernier. 1995. Stomatal and mesophyll limitations of photosynthesis in black spruce seedlings during multiple cycles of drought. Tree Physiology 15:5764.

Tan, W., T. J. Blake, and T. J. B. Boyle. 1992. Drought tolerance in faster- and slower-growing black spruce (Picea mariana) provenances: II. Osmotic adjustment and changes of soluble carbohydrates and amino acids under osmotic stress. Physiologia Plantarum 85:645-651.

Tardieu, F. and W. J. Davies. 1993. Integration of hydraulic and chemical signalling in the control of stomatal conductance and water status of droughted plants. Plant, Cell and Environment 16: 341-349.

Tognetti, R., M. Michelozzi, and A. Giovannelli. 1997. Geographical variation in water relations, hydraulic architecture and terpene composition of Aleppo pine seedlings from Italian provenances. Tree Physiology 17:241-259.

Whitehead, D., N. J. Livingston, F. M. Kelliher, K. P. Hogan, S. Pepin, T. M. McSeveny, and J. N. Byers. 1996. Response of transpiration and photosynthesis to a transient change in illuminated foliage area for a Pinus radiata D. Don tree. Plant, Cell and Environment 19:949-957.

Williams, M., E. B. Rastetter, D. N. Fernandes, M. L. Goulden, S. C. Wofsy, G. R. Shaver, J. M. Melillo, J. W. Munger, S.-M. Fan, and K. J. Nadelhoffer. 1996. Modelling the soil-plant-atmosphere continuum in a Quercus-Acer stand at Harvard Forest: the regulation of stomatal conductance by light, nitrogen and soil/plant hydraulic properties. Plant, Cell and Environment 19:911-927.

Wilson, C. V. 1971. The Climate of Quebec. Climatic Atlas: Part One. Meteorological Service of Canada, Ottawa, ON, Canada.

Zine El Abidine, A., P. Y. Bernier, J. D. Stewart, and A. P. Plamondon. 1994. Water stress preconditioning of black spruce seedlings from lowland and upland sites. Canadian Journal of Botany 72:1511-1518

Zwiazek, J. J. and T. J. Blake. 1989. Effects of preconditioning on subsequent water relations, stomatal sensitivity, and photosynthesis in osmotically stressed black spruces. Canadian Journal of Botany 67:2240-2244.

Manuscript received 22 February 2001; revisions received 10 December 2001; accepted 4 January 2002. 